\title{
Use of a nursery area by cownose rays (Rhinopteridae) in southeastern Brazil
}

\author{
Bianca S. Rangel ${ }^{1}$, Alexandre Rodrigues ${ }^{2}$ and Renata G. Moreira ${ }^{1}$
}

Using non-lethal methods for data collection of individuals and participatory monitoring by fishermen, we provide the first empirical evidence of the use of a nursery area by neonate and young-of-the-year cownose rays Rhinoptera bonasus and $R$. brasiliensis in southeastern Brazil. Two methods were used to collect data: (1) information provided by fishermen (reports, pictures, and videos) and (2) field sampling by researchers. A total of 746 cownose rays were captured; 113 have been identified as $R$. bonasus, 15 as $R$. brasiliensis, and 618 were reported by fishermen and could not be identified to the species. Records of newborns were made only in late spring and summer in 2015, 2016, and 2017, which suggests an annual reproductive cycle, with birth in late spring, extending to summer. A repeated use of this area by $R$. bonasus suggests that it is potentially important to the reproduction of this species. However, R. brasiliensis requires more studies. Small increases in mortality, resulting from increased fishing or other anthropogenic stressors, can have a disproportionately large effect on population viability. Thus, management of areas used during critical stages of the life cycle of rays is crucial to their conservation.

Keywords: Early life-history, Neonates, Newborn, Non-lethal, Young of the year.

Usando métodos não-letais para levantamento de dados dos indivíduos e o monitoramento participativo dos pescadores fornecemos a primeira evidência empírica do uso de uma área de berçário por neonatos e jovens do ano de raias Ticonha Rhinoptera bonasus e R. brasiliensis no sudeste do Brasil. Dois métodos foram utilizados para coletar dados: (1) informações fornecidas pelos pescadores (relatórios, fotos e vídeos) e (2) amostragem de campo pelos pesquisadores. Um total de 746 raias Ticonha foram capturadas; 113 foram identificadas como $R$. bonasus, 15 como $R$. brasiliensis e 618 foram registrados pelos pescadores e não puderam ser identificadas em nível específico. Os registros de recém-nascidos foram feitos apenas no final da primavera e no verão de 2015, 2016 e 2017, o que sugere um ciclo reprodutivo anual, com nascimento no final da primavera, se estendendo até o verão. O uso repetido desta área por $R$. bonasus sugere sua potencial importância para a reprodução destas espécies. No entanto, $R$. brasiliensis requer mais estudos. Pequenos aumentos na mortalidade, resultantes do aumento da pesca ou outros estressores antropogênicos, podem ter um efeito desproporcionalmente grande na viabilidade populacional. Assim, o gerenciamento das áreas usadas durante os estágios críticos do ciclo de vida das raias é crucial para sua conservação.

Palavras-chave: Início da história da vida, Jovens do ano, Não letal, Neonatos, Recém nascido.

\section{Introduction}

Due to their peculiar biological characteristics, such as late sexual maturity, long gestation period, and low reproductive potential, batoids (skates and rays) are highly susceptible to anthropogenic stressors (e.g. by overexploitation and persistent organic pollutants) (Gelsleichter et al., 2006; Dulvy et al., 2014; Sawyna et al., 2016). Therefore, the identification of critical areas involved in the life cycle of these fish is essential for their management and conservation
(Heithaus, 2007; Tavares et al., 2016). Nursery areas of elasmobranchs are usually located in shallow estuarine or coastal areas, where there is protection against predators and abundant food, which enables permanence in the first few months or years of their life (Springer, 1967; Castro, 1993; Heupel et al., 2007). Although nursery areas of sharks have been well-studied (Gadig et al., 2002; Heithaus, 2007; Bornatowski, 2008; Kinney, Simpfendorfer, 2009), little is known about the nursery areas of batoids (Cerutti-Pereyra et al., 2004; Yokota, Lessa, 2006; Araújo et al., 2016).

\footnotetext{
${ }^{1}$ Laboratório de Metabolismo e Reprodução de Organismos Aquáticos, Departamento de Fisiologia, Instituto de Biociências, Universidade de São Paulo. Rua do Matão, travessa 14, 321, 05508-090 Cidade Universitária, São Paulo, SP, Brazil. (BSR) biarangel.sea@gmail.com, (RGM) renatagm@ib.usp.br, Ohttps://orcid.org/0000-0001-8139-1776 (corresponding author).

${ }^{2}$ Laboratório de Biologia e Genética de Peixes, Instituto de Biociências de Botucatu, Universidade Estadual Paulista. Rua Prof. Dr. Antonio Celso Wagner Zanin, s/n, 18618-689, Botucatu, SP, Brazil. (AR) tubabiomar@hotmail.com.
} 
Cownose rays (Chondrichthyes; Rhinopteridae) are benthopelagic, with large schools often reported in estuarine and coastal regions, grouped by size and sex (Smith, Merriner, 1987; Schwartz, 1990; Fisher et al., 2013; Ajemian, Powers, 2016). They occur in temperate and tropical regions, migrate, and breed in seasonal cycles (Grusha, 2005; Fisher et al., 2013; Ajemian, Powers, 2016). Although most of the biological knowledge about cownose rays comes from northern populations of Rhinoptera bonasus (Mitchill, 1815) (Neer, Thompson, 2005; Fisher, 2010; Fisher et al., 2013; Ajemian, Powers, 2016), other congeneric species share its life history strategy (McEachran, Carvalho, 2002; Domingues et al., 2009; Rangel et al., 2017).

When adults, cownose rays use different areas for breeding (in summer) and feeding (in winter). Mating occurs in an annual (Fig. 1) (Fisher, 2010; Ajemian, Powers, 2016) or biennial cycle (Pérez-Jiménez, 2011), and pregnant females access the nursery areas to give birth. Some of these critical areas are known for a few populations in the northern hemisphere (Neer, Thompson, 2005; Collins et al., 2008; Fisher et al., 2013; Ajemian, Powers, 2016). However, knowledge about the biology of $R$. bonasus and $R$. brasiliensis Müller, 1836 in the southern hemisphere is poor, with occasional reports of potential nursery areas (Domingues et al., 2009).

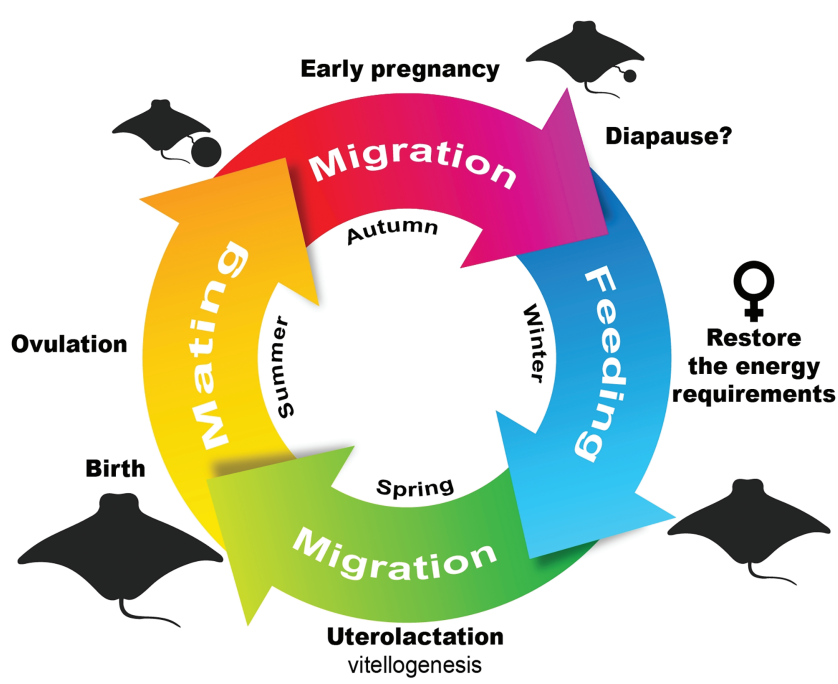

Fig. 1. Diagram of the reproductive cycle of Rhinoptera bonasus, based on data from the present study and Smith, Merriner (1987), Blaylock (1993), Fisher (2010), Goodman et al. (2010), Fisher et al. (2013), and Ajemian, Powers (2016).

Rhinoptera bonasus occurs from southern New England (USA) to southern Brazil, including the Gulf of Mexico (Bigelow, Schroeder, 1953; McEachran, Carvalho, 2002). It is currently classified as "Near Threatened" on the International Union for the Conservation of Nature (IUCN) Red List assessment (Barker, 2006), and is listed in Appendix II of the list of endangered species of wildlife in the State of São Paulo, as a species that requires care in fishery management for its conservation (ALESP, 2014).
Rhinoptera brasiliensis is classified as "Endangered" on the IUCN Red List and as "Critically Endangered" on the Brazilian national assessment (ICMBio, 2016), and shows a more restricted distribution, occurring in the Gulf of Mexico, Colombia (Caribbean coast), and from Venezuela to southern Brazil (McEachran, Carvalho, 2002; Grijalba-Bendeck et al., 2007; Lasso-Alcalá et al., 2009). Basic studies on life history aspects are urgently required in Brazil (Vooren, Lamónaca, 2004). A few studies were carried out only at genus level (Rhinoptera spp.), making difficult of raising what has already been achieved in monitoring and reports of occurrence of these populations in Brazil (Cavalcante et al., 1997; Vooren et al., 2005; Costa, Chaves, 2006).

The recovery of impacted elasmobranchs populations requires attention in all age classes (Kinney, Simpfendorfer, 2009). Factors such as recruitment, survival of the parental stock and protection of nursery areas, are important for the stability of populations (Camhi et al., 1998; Dulvy et al., 2014). Despite the concern about the conservation of elasmobranchs, knowledge of nursery areas is still poor (Yokota, Lessa, 2006; Tavares et al., 2016). Thus, the goal of the present study was to assess the potential use of a nursery area by the cownose rays $R$. bonasus and $R$. brasiliensis during early stages of life. We highlight the bycatch in small-scale artisanal fisheries on the central coast of the state of São Paulo, southeastern Brazil, the use of a non-lethal methodology for data collection of individuals and participatory monitoring by fishermen for research and monitoring of neonates and young of the year (YOY). We discuss the implications of the reproductive strategy of these species, the importance of monitoring them in this region, and the limitations of assessing the neonatal period in cownose rays with the criteria proposed for elasmobranchs, as they have different reproductive strategies.

\section{Materials and Methods}

The rays were collected from November 2015 to May 2017 in Bertioga, Guaibe Sector, a Marine Protected Area located in the São Paulo coast, southeastern Brazil $\left(23^{\circ} 49^{\prime} 35.02^{\prime \prime} \mathrm{S}, 46^{\circ} 5^{\prime} 41.69^{\prime \prime} \mathrm{W}\right)$ (Fig. 2). The specimens sampled were obtained from the bycatch of the beach seine fishing, using a $350 \times 11 \mathrm{~m}$ fishing net, mesh-size of the $70 \mathrm{~mm}$ between knots in the wings and $80 \mathrm{~mm}$ in the bag, thrown at 400-600 $\mathrm{m}$ from the beach and the gathered by manual traction.

After fishing, two methods were used to collect data of individuals: (1) information provided by fishermen (reports, pictures, and videos) and (2) field sampling by researchers (Fig. 3). The information collected by fishermen through images and capture reports were: popular name of rays, number of individuals, date and local of capture. The rays were released immediately (approximately 5 minutes). Animals that died in the process were also analyzed and then kept by fishermen. 


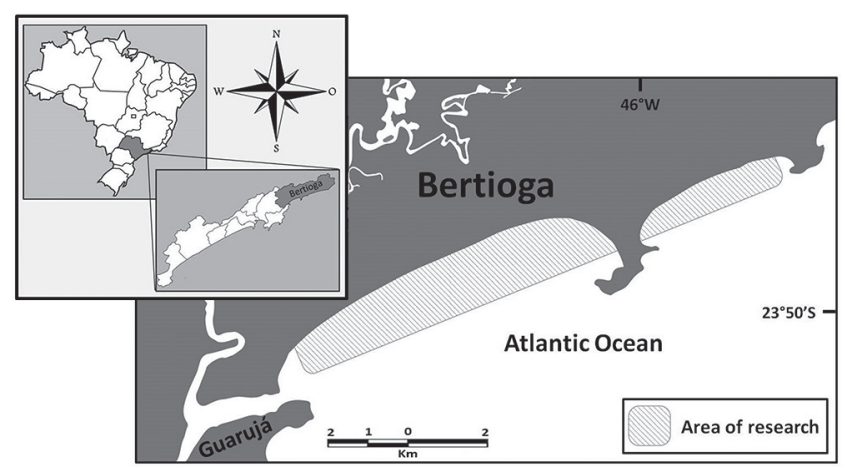

Fig. 2. Map of the location where the animals were caught in Bertioga, São Paulo, southeastern Brazil (2349’35.02” S, 46 5'41.69" W).

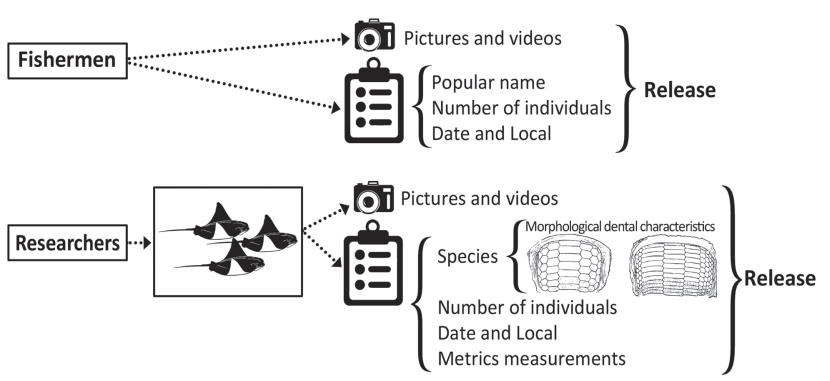

Fig. 3. Methods to collect data of individuals: (top) information provided by fishermen (reports, pictures, and videos) and (down) field sampling by researchers.

During the sampling by researchers, the animals were removed from the fishing net and stored in plastic containers (50L) filled with seawater ( 2 or 3 individuals per box) to reduce air exposure during the procedures of metric measurements (disc width-DW). Species were identified through morphological dental characteristics (counting the rows of teeth). Rhinoptera brasiliensis presents nine rows in the dental plates and $R$. bonasus presents seven rows of teeth (McEachran, Carvalho, 2002). The animals were released at the end of data collection (approximately 30 minutes).

For a preliminary analysis of possible periods of birth, the $R$. bonasus were classified as neonates $(<50 \mathrm{~cm})$ or YOY $(>$ $50 \mathrm{~cm}$ and $<70 \mathrm{~cm}$ ), using the study of age and growth of Fisher (2010) and Fisher et al. (2013). For the R. brasiliensis the same classification was used, since the two species have similar size at birth. However, this is not a study about age and/or growth of $R$. brasiliensis.

The criteria proposed by Heupel et al. (2007) was used to define nursery area and all the three criteria seem to fit, at least to the region of Bertioga, state of São Paulo. (1) There is more YOY in this region than in surrounding regions (Domingues et al., 2009). (2) YOY tend to remain for long periods in place. In the present study, there were individuals with little more than a year (individual $>60 \mathrm{~cm}$, with $\sim 1$ year old). (3) The habitat is repeatedly used over the years. Research permits were granted by SISBIO (ICMBIO/SISBIO \# 48572-1) and the Animal Ethics Committee (CEUA; \# 258/2016) of the Institute of Biosciences, University of São Paulo.

\section{Results}

A total of 746 cownose rays were captured: 113 were identified as $R$. bonasus, 15 as $R$. brasiliensis, and 618 were reported by fishermen and could not be identified to the species level. The largest number of animals recorded was obtained through pictures and videos made by fishermen (Figs. 4 a-c) and reports (as shown in the video S1 - Available only as online supplementary file accessed with the online version of the article at http://www.scielo. br/ni). Data provided by fishermen is an effective tool in the monitoring of these rays at the study site, allowed to quantify the amount of animals captured and to estimate the life-stage (young or adult).

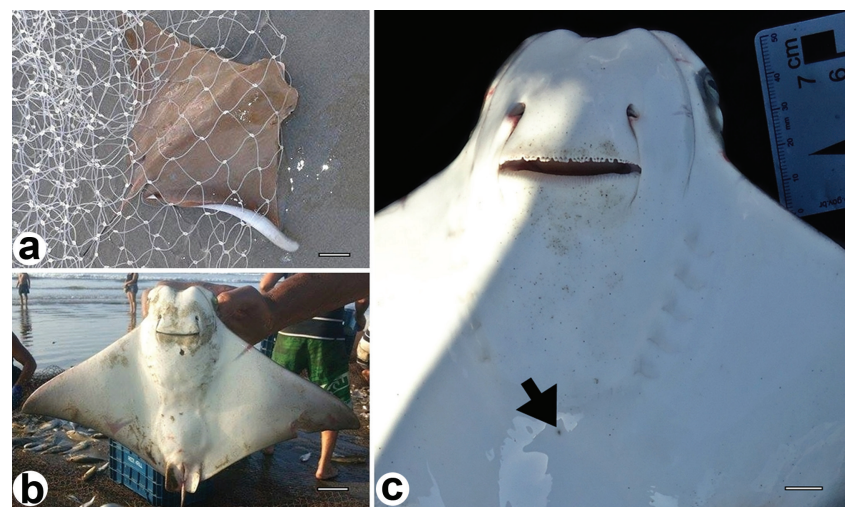

Fig. 4. a. Rhinoptera spp. YOY captured, still on the net. b. Rays being released by fishermen. c. Individual ray recorded with the scar of the umbilical cord (arrow). Scale bar: a. 3.5 cm; b. $3 \mathrm{~cm}$; c. $1 \mathrm{~cm}$.

The largest catches of neonates and YOY were made in late spring, throughout summer, and in early fall (Fig. 5). Large schools of 20-55 animals were captured between November and March inside the bay (Fig. 2). The largest school recorded comprised 55 individuals (including neonates and YOY), but the average number of animals in school was $34 \pm 12.07$. In these events, due to the large number of individuals captured, only a few were measured.

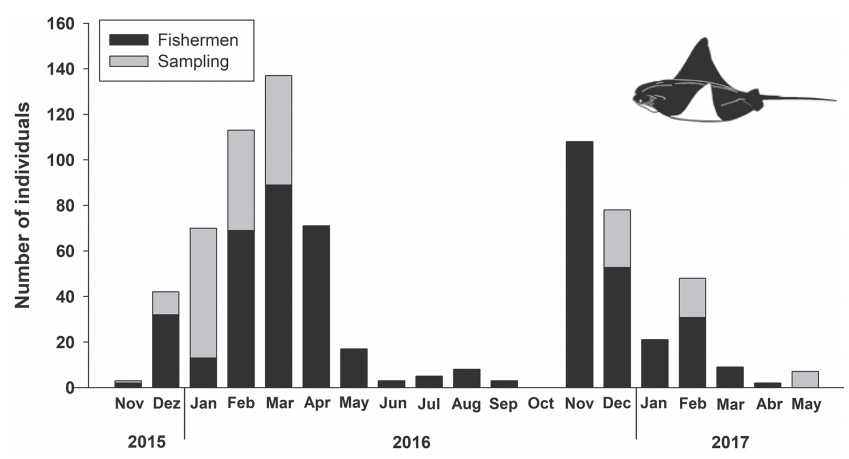

Fig. 5. Number of monthly catches of Rhinoptera spp. neonates and YOY in Bertioga, São Paulo, southeastern Brazil (November 2015 - May 2017). 
Among the animals measured and identified $(\mathrm{n}=$ 128), $R$. bonasus was more frequent $(\mathrm{n}=113)$ than $R$. brasiliensis $(\mathrm{n}=15)$. In $R$. bonasus, the amplitude of $\mathrm{DW}$ was $31.5-75 \mathrm{~cm}$, and in $R$. brasiliensis, $35.5-58.5 \mathrm{~cm}$ (Fig. 6a). Few individuals analyzed showed umbilical scars, $R$. bonasus ( $=5,39.5 \pm 3.12 \mathrm{~cm} \mathrm{DW)} \mathrm{(Fig.} 4 \mathrm{c}$ ) and $R$. brasiliensis $(\mathrm{n}=1,45.5 \mathrm{~cm} \mathrm{DW})$. Smaller animals $(35.8 \pm 6.01 \mathrm{~cm} \mathrm{DW}, \mathrm{n}=3)$ were recorded without any evidence of umbilical scars.

The smallest individuals captured (some with umbilical scars) were recorded in December (2015 and 2016) and February (2017) (Fig. 6b). The only adult individual was captured in February (2017), together with neonates. All rays captured were released immediately by fishermen and researchers, with very few reports of mortality $(1.2$ $\%)(n=15)$, which occurred during night trawls and when a high number of teleost were caught, making difficult to locate rays during fish removal. Dead animals included nine $R$. bonasus $(31.5-48 \mathrm{~cm})$ and six $R$. brasiliensis $(35.5-54 \mathrm{~cm})$.
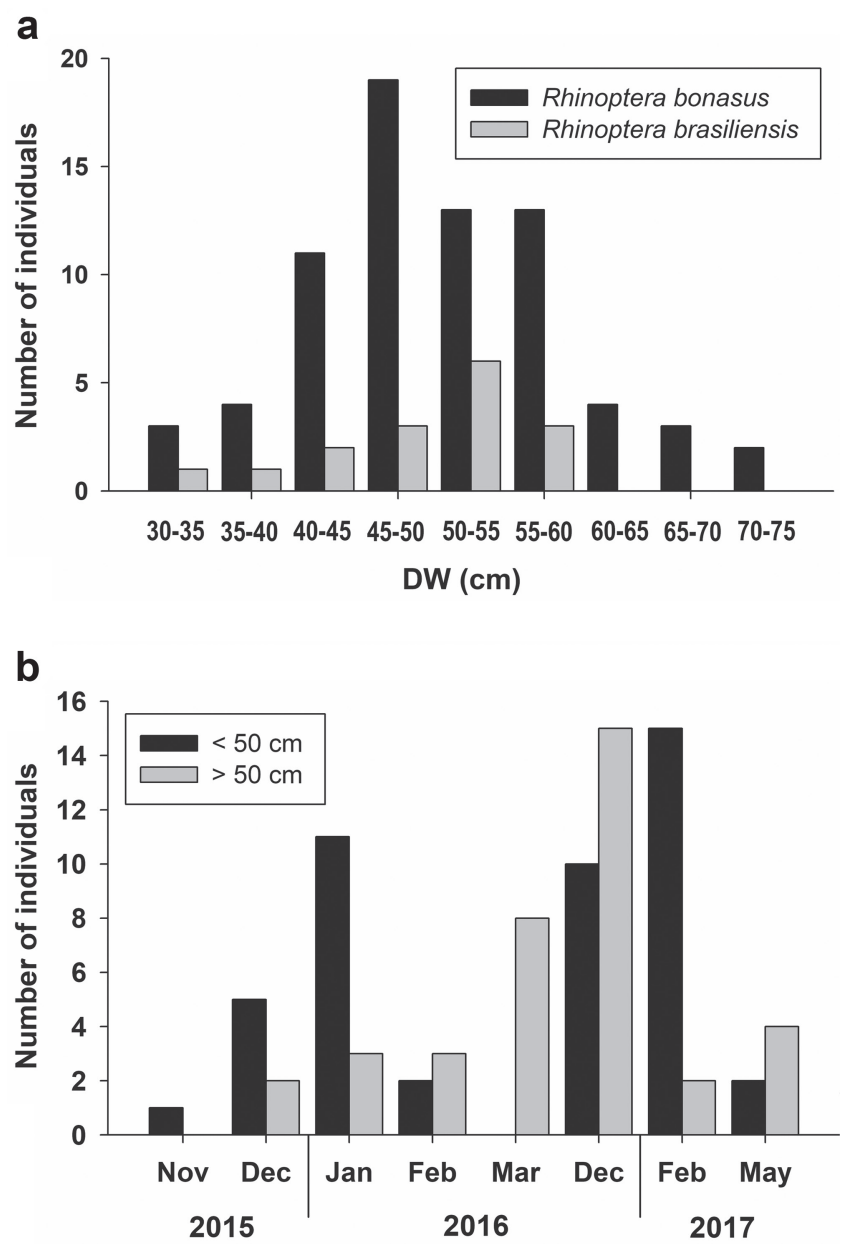

Fig. 6. a. Number of Rhinoptera bonasus and $R$. brasiliensis according to disc width (DW) and b. individuals $<50 \mathrm{~cm}$ and $>50 \mathrm{~cm}$ in the months sampled in Bertioga, São Paulo, southeastern Brazil (November 2015 - May 2017).

\section{Discussion}

This study is the first empirical evidence of the use of a nursery area by neonate and YOY cownose rays (Rhinoptera bonasus and R. brasiliensis) in southeastern Brazil. The reproductive cycle of $R$. bonasus and $R$. brasiliensis are poorly known in the study region. However, the record of newborns only during the late spring and summer in 2015, 2016, and 2017 suggests an annual cycle, with birth in late spring, extending during the summer (Fig. 5), confirming the criterion proposed by Heupel et al. (2007). The seasonality of catches seems to be related to the low frequency of fishing during late autumn and winter (from June to October), due to frequent changes in the temperature and oceanographic conditions in this period. It is also likely that pregnant females migrate to this region to mate and give birth (i.e., Smith, Merriner, 1987; Fisher et al., 2013). Several studies on the migratory behavior of $R$. bonasus in the northern hemisphere confirmed the arrival of migratory parental rays in coastal and estuarine waters in mid-spring, where they remain throughout summer and migrate again in the middle of late autumn (Fig. 1) (Smith, Merriner, 1987; Schwartz, 1990; Blaylock, 1993; Neer, Thompson, 2005; Goodman et al., 2010; Ajemian, Powers, 2016). However, due to the capture of YOY throughout the year, animals may remain in the nursery area until the next migration season. They probably stay in nursery areas due to their low mobility at this age (Ajemian, Powers, 2016), to maximize growth and protection against predators (Fisher et al., 2013), and even because of their low energy stocks at this stage of life.

The presence of neonates and YOY were punctually recorded only in the State of Paraná, southern Brazil (n = 51 ; DW $=38.0-95.0 \mathrm{~cm}$; Bornatowski et al., 2014) and in the State of Rio Grande do Norte, northeastern Brazil (n $=4$; Yokota, Lessa, 2006; and $\mathrm{n}=9 ; \mathrm{DW}=34.5-45 ;$ Lessa et al., 2015). There is capture data for $R$. brasiliensis in the state of Rio Grande do Sul, southern Brazil, during summer 1982-1985, with large schools composed of males with 78-91 cm (DW) and females with 77 to $102 \mathrm{~cm}$ (DW) (Vooren, Lamónaca, 2004). There are no records of the capture of newborns in Rio Grande do Sul, which suggests that birth and nursery area occur in some region further north (Vooren, Lamónaca, 2004). Pregnant females were occasionally captured in the Guarujá, state of São Paulo (Domingues et al., 2009), a region near the study area. Therefore, the present study is the first to record a large number of neonates and YOY of this species $(n=15)$.

Reports of newborns and embryos to term of $R$. brasiliensis suggest that the size at birth is 43 to $48 \mathrm{~cm}$ DW (Bigelow, Schroeder, 1953; Vooren, Lamónaca, 2004; Domingues et al., 2009). In the present study, individuals captured measured $35.5-58.5 \mathrm{~cm}$ (DW), representing neonates and YOY. The smallest newborn pup recorded 
was captured in May, together with the information of a pregnant female in March and neonates in October (Domingues et al., 2009), and pregnant females in middle of the gestation in January, in Rio Grande do Sul State (Vooren, Lamónaca, 2004). Therefore, the time of birth and the reproductive cycle can be different from that observed in the present study for R. bonasus. However, more studies are required comprising the entire reproductive cycle of this species.

Some of the features observed in shark nursery areas can be applied to the present study, considering that these areas are characterized by both, the presence of pregnant females and the occurrence of newborns (Springer, 1967; Castro, 1993; Simpfendorfer, Milward, 1993). In sharks and other batoid species, the identification of neonates and YOY is based on the presence of an umbilical cord mark (Hussey et al., 2010; Belicka et al., 2012). However, in stingrays that exhibit histotrophic viviparity, the embryo consumes the yolk sac long before birth (Fisher, 2010). Thus, the scar is almost unnoticeable, which makes the identification difficult. In Rhinoptera spp., DW was used for classification into neonates and YOY, as only five rays show umbilical scars.

Rhinoptera bonasus shows ontogenetic segregation, with YOY and juveniles exploring coastal bays with fluvial influence or estuarine regions with low salinity, avoiding the competition with the pups of other age classes and protected from predators (Ajemian, Powers, 2016). Apparently, the same occur with $R$. brasiliensis. This information corroborates our findings because the region studied forms bays and undergoes fluvial influence. By capturing large groups of neonates and YOY, Fisher et al. (2013) and Ajemian, Powers (2016) noted that grouping could reduce the predatory effect at the beginning of life, bringing food advantage to these animals (Bedore et al., 2014; Rangel et al., 2017). Only ten juveniles $(34 \mathrm{~cm}$ ) and ten adults (images provided by fishermen) were recorded, which indicates either that they eventually come back or remain in more coastal nursery areas. However, further studies are required addressing other fishing gear with larger expanse to identify the local use of other age classes.

Rhinoptera bonasus and $R$. brasiliensis were routinely caught together, both neonates and YOY (Rangel et al., 2017). The common use of the area can bring advantages to newborns, reducing predation, but also disadvantages, such as possible competition for resources (Heupel et al., 2007). The sympatric and syntopic occurrence of $R$. bonasus and $R$. brasiliensis can increase the chances of survival and feeding success during the first few months or weeks of life (Rangel et al., 2017). Studies investigating the relationship between trophic relationship and habitat use of newborn pups of two species using stable isotopes and fatty acids (Belicka et al., 2012) can reveal how these species are sharing resources in the nursery area.
Due to the difficulty of managing populations of sharks and rays by traditional strategies used for fish, such as size limits (for age class) and fishing regulations and quotas (Heithaus, 2007), management of areas used during critical stages of the life cycle of these animals could help the conservation of these populations. The repeated use of the area by $R$. bonasus and $R$. brasiliensis suggests that it is important to the life history of these species. Small increases in mortality from increased fishing or other anthropogenic stressors can have a disproportionately large effect on the population viability (Walters, Martell, 2004), especially in critical stages of life history (Heupel, Simpfendorfer, 2002; Hussey et al., 2010).

Monitoring newborns and adults with the help of fishermen has been very efficient; it was possible to identify individuals to the genus level and the frequency of captures during the year. In addition, the immediate release of rays by fishermen proved to be a proper management, ensuring the survival of animals after the capture by beach seine. We recommend marking individuals released with plastic or transmitter for the assessment of the real post-released survival of these animals. Furthermore, as Bertioga is a region with high anthropogenic impact (Gonçalves et al., 2013), studies on contaminants and the impact of climate change are needed. On the one hand, the premature abandonment of newborns can hinder survival, exposing them to severe predation pressure (Springer, 1967) and energy challenges that they are not ready to deal with yet. On the other hand, staying too long in this region can result in competition the juveniles ( $>$ one year old) and newborns.

In conclusion, we identified the area as a nursery for both cownose ray species. Birth occurs in late spring and early summer. The method used for classifying neonate elasmobranchs is inaccurate for Rhinoptera, which have a matrotrophic (histotrophic) reproductive mode. However, more detailed analyses are necessary in a higher number of species to evaluate the umbilical cord scar and its effectiveness in the classification of the puppies. A new method should be developed for separating neonates from YOY. Additionally, inclusion of the pregnant females and analysis of embryos, as well as age and growth studies and biochemical analyses, such as stable isotopes will help to improve our understanding for correct classification of newborns. The beach seine method proved to have lowimpact on rays in post-capture when prioritized the release soon after capture.

\section{Acknowledgments}

We thank Fundação de Amparo à Pesquisa do Estado de São Paulo (FAPESP 2014/16320-7) for funding and for the Master's scholarship to B.S. Rangel (FAPESP 2016/09095-2), the fishermen Wesley Shkola for obtaining the animals and information's (videos, images and annotation) and Vanessa Paes da Cruz for assistance in projects and field collections. 


\section{References}

Ajemian MJ, Powers SP. Seasonality and ontogenetic habitat partitioning of cownose rays in the Northern Gulf of Mexico. Estuaries Coast. 2016; 39(4):1234-48.

Araújo PRV, Oddone MC, Velasco G. Reproductive biology of the stingrays, Myliobatis goodei and Myliobatis ridens (Chondrichthyes: Myliobatidae), in southern Brazil. J Fish Biol. 2016; 89(1):1043-67.

Assembleia Legislativa do Estado de São Paulo (ALESP). Decreto $N^{\circ}$ 60.133, de 7 de Fevereiro de 2014: As espécies da fauna silvestre ameaçadas de extinção, as quase ameaçadas e as deficientes de dados para avaliação no Estado de São Paulo e dá providências correlatas. 2014. Available from: https://www.al.sp.gov.br/repositorio/legislacao/decreto/2014/ decreto-60133-07.02.2014.html

Barker AS. Rhinoptera bonasus: The IUCN Red List of Threatened Species: e.T60128A12310195 [Internet]. 2006 [cited 2017 Mar 10]. Available from: http://dx.doi.org/10.2305/IUCN. UK.2006.RLTS.T60128A12310195.en

Bedore CN, Harris LL, Kajiura SM. Behavioral responses of batoid elasmobranchs to prey-simulating electric fields are correlated to peripheral sensory morphology and ecology. Zoology (Jena). 2014; 117(2):95-103.

Belicka LL, Matich P, Jaffé R, Heithaus MR. Fatty acids and stable isotopes as indicators of early-life feeding and potential maternal resource dependency in the bull shark Carcharhinus leucas. Mar Ecol Prog Ser. 2012; 455:245-56.

Bigelow HB, Schroeder WC. Fishes of the Western North Atlantic. New Haven: Sears Foundation for Marine Research, Yale University; 1953. pt. 2, Sawfishes, guitarfishes, skates and rays: Chimaeroids. (Sears Foundation for Marine Research; No. 1).

Blaylock RA. Distribution and abundance of the cownose ray, Rhinoptera bonasus, in lower Chesapeake Bay. Estuaries Coast. 1993; 16(2):255-63.

Bornatowski H. A parturition and nursery area for Carcharhinus limbatus (Elasmobranchii, Carcharhinidae) off the coast of Paraná, Brazil. Braz J Oceanogr. 2008; 56(4):317-19.

Bornatowski H, Wosnick N, Carmo WPD, Corrêa MFM, Abilhoa, V. Feeding comparisons of four batoids (Elasmobranchii) in coastal waters of southern Brazil. J Mar Biol Assoc UK. 2014; 94(7):1491-99.

Camhi M, Fowler S, Musick J, Brautigam A, Fordham FS. Sharks and their relatives: ecology and conservation. Gland, Switzerland and Cambridge, UK: IUCN/Species Survival Commission Shark Specialist Group; 1998. (Occasional Paper of the IUCN Species Survival Commission; No. 20).

Castro JI. The shark nursery of Bulls Bay, South Carolina, with a review of the shark nurseries of the southeastern coast of the United States. Environ Biol Fishes. 1993; 38(1-3):37-48.

Cavalcanti MJ, Gallo-da-Silva V, Afonso AF. Identificação de Rhinoptera bonasus (Mitchill, 1815) e R. brasiliensis Müller \& Henle, 1841 (Chondrichthyes, Myliobatiformes, Rhinopteridae) pela análise de funções discriminantes. Acta Biologica Leopoldensia. 1997; 19(2):205-15.
Cerutti-Pereyra F, Thums M, Austin CM, Bradshaw CJA, Stevens JD, Babcock, RC, Pilland RD, Meekan MG. Restricted movements of juvenile rays in the lagoon of Ningaloo Reef, Western Australia - evidence for the existence of a nursery. Environ Biol Fishes. 2014; 97(4):371-83.

Collins AB, Heupel MR, Simpfendorfer C. Spatial distribution and long-term movement patterns of cownose rays Rhinoptera bonasus within an estuarine River. Estuaries Coast. 2008; 31(6):1174-83.

Costa L, Chaves PTC. Elasmobrânquios capturados pela pesca artesanal na costa sul do Paraná e norte de Santa Catarina, Brasil. Biota Neotropica. 2006; 6(3):bn02706032006.

Domingues RR, Gonzalez, MMB, Amorim, AF. First reported occurrence of pregnant and neonato, Rhinoptera brasiliensis (Chondrichthyes, Rhinopteridae) caught off Guaruja city, São Paulo state, Brazil. Panam J Aqua Sci. 2009; 4(4):605-08.

Dulvy NK, Fowler SL, Musick JA, Cavanagh RD, Kyne PM, Harrison LR et al. Extinction risk and conservation of the world's sharks and rays. eLife. 2014; 3(1):e00590.

Fisher RA. Life history, trophic ecology, \& prey handling by cownose ray, Rhinoptera bonasus, from Chesapeake Bay: (NA07NMF4570324), Report to NOAA (Grant No. 713031). Gloucester Point: Virginia Institute of Marine Science/ NOAA/Sea Grant; 2010. (VIMS Marine Resource Report; No. 2010-10).

Fisher RA, Call GC, Grubbs RD. Age, growth, and reproductive biology of cownose rays in Chesapeake Bay. Mar Coast Fish. 2013; 5(1):224-35.

Gadig OBF, Motta FS, Namora RC. Projeto Cação: a study on small coastal sharks in São Paulo, southeast Brazil. In: Duarte $\mathrm{P}$, editor. Proceedings for the International Conference on Sustainable Management of Coastal Ecosystems. Porto: Universidade Fernando Pessoa; 2002. p.239-246.

Gelsleichter J, Walsh CJ, Szabo NJ, Rasmussen LE. Organochlorine concentrations, reproductive physiology, and immune function in unique populations of freshwater Atlantic stingrays (Dasyatis sabina) from Florida's St. Johns River. Chemosphere. 2006; 63(9):1506-22.

Gonçalves C, Figueira RCL, Sartoretto JR, Salaroli AB, Kim BSM, Mahiques MM. Evaluation of anthropic influences in an estuarine system of Southeastern Brazilian Coast by applying enrichment factors. E3S Web of Conferences. 2013; 1(32010):1-3.

Goodman MA, Conn PB, Fitzpatrick E. Seasonal occurrence of cownose rays (Rhinoptera bonasus) in North Carolina's estuarine and coastal waters. Estuaries Coast. 2010; 34(3):640-51.

Grijalba-Bendeck M, Polo-Silva C, Acero AP. Una aproximación a la abundancia de los batoideos capturados artesanalmente en Santa Marta (Colombia). Boletín de Investigaciones Marinas y Costeras (INVEMAR). 2007; 36(1):251-68.

Grusha DS. Investigation of the life history of the cownose ray, Rhinoptera bonasus (Mitchill 1815). [PhD Thesis]. Gloucester Point, VA: Faculty of the School of Marine Science and College of William and Mary in Virginia; 2005.

Heithaus MR. Nursery areas as essential shark habitats: a theoretical perspective. Am Fish Soc Sym. 2007; 50(3):3-13. 
Heupel MR, Simpfendorfer CA. Estimation of mortality of juvenile blacktip sharks, Carcharhinus limbatus, within a nursery area based on telemetry data. Can J Fish Aquat Sci. 2002; 59(4):624-32.

Heupel MR, Carlson JK, Simpfendorfer CA. Shark nursery areas: concepts, definition, characterization and assumptions. Mar Ecol Prog Ser. 2007; 337:287-97.

Hussey NE, Wintner SP, Dudley SFJ, Cliff G, Cocks DT, MacNeil MA. Maternal investment and size-specific reproductive output in carcharhinid sharks. J Anim Ecol. 2010; 79(1):184-93.

Instituto Chico Mendes de Conservação da Biodiversidade (ICMBio). Avaliação do risco de extinção dos elasmobrânquios e quimeras no Brasil: 2010-2012. Itajaí: CEPSUL, 2016.

Kinney MJ, Simpfendorfer CA. Reassessing the value of nursery areas to shark conservation and management. Conserv Lett. 2009; 2(2):53-60.

Lasso-Alcalá OM, Lasso CA, Rodríguez JC. Comunidad de peces demersales del sector suroriental del golfo de Paria, Venezuela. Memoria de la Fundación La Salle de Ciencias Naturalles. 2009; 170:99-124.

Lessa R, Rodrigues J, Barreto R, Nunes R, Camargo G, Santana FM. Pesca Incidental de Rajiformes nos arrastos de praia em Caiçara do Norte, RN. Revista Brasileira de Engenharia de Pesca. 2015; 8(2):34-41.

McEachran JD, Carvalho MR. Batoid fishes. In: Carpenter, KE, editor. The living marine resources of the Western Central Atlantic.Rome: Food and Agriculture Organization of the United Nations; 2002. vol 1, Introduction, molluscs, crustaceans, hagfishes, sharks, batoid fishes, and chimaeras. p.508-589 (FAO species identification guide for fishery purposes and American Society of Ichthyologists and Herpetologists Special Publication; No. 5).

Neer JA, Thompson BA. Life history of the cownose ray, Rhinoptera bonasus, in the northern Gulf of Mexico, with comments on geographic variability in life history traits. Environ Biol Fishes. 2005; 73(3):321-31.

Pérez-Jiménez JC. Biología reproductiva de la raya Rhinoptera bonasus (Elasmobranchii) en el sureste del Golfo de México. Hidrobiologica. 2011; 21(2):159-67.

Rangel BS, Cruz VP, Rodrigues A, Araujo MLG, Oliveira C, Foresti F, Moreira RG. Sympatric and syntopic occurrence of cownose rays: Neonatal strategies for survival? J Appl Ichthyol. 2017; 33(3):542-45.
Sawyna JM, Spivia WR, Radecki K, Fraser DA, Lowe CG. Association between chronic organochlorine exposure and immunotoxicity in the round stingray (Urobatis halleri). Environ Pollut. 2017; 223:42-50.

Schwartz FJ. Mass migratory congregations and movements of several species of cownose rays, genus Rhinoptera: a worldwide review. J Elisha Mitchell Sci Soc. 1990; 106(1):10-13.

Simpfendorfer CA, Milward NE. Utilization of a tropical bay as a nursery area by sharks of the families Carcharhinidae and Sphyrnidae. Environ Biol Fishes. 1993; 37(4):337-45.

Smith JW, Merriner JV. Age and growth, movements and distribution of the cownose ray, Rhinoptera bonasus, in Chesapeake Bay. Estuaries. 1987; 10(2):153-64.

Springer S. Social organization of shark populations. In: Gilbert PW, Mathewson RF, Rall DP, editors. Sharks, skates and rays. Baltimore: John Hopkins Press; 1967; p.149-174.

Tavares R, Rodriguez JP, Morales M. Nursery area and size structure of the lemon shark population, Negaprion brevirostris (Poey, 1868), in Los Roques Archipelago National Park, Venezuela. Univ Scie (Bogota). 2016; 21(1):33-52.

Vooren CM, Klippel S, Galina AB. Os elasmobrânquios das águas costeiras da Plataforma Sul. In: Vooren CM, Klippel S, editors. Ações para a conservação de tubarões e raias no sul do Brasil. Porto Alegre: Igaré; 2005.p.113-120.

Vooren CM, Lamónaca AF. Rhinoptera brasiliensis: The IUCN Red List of Threatened Species: e.T44595A10912274 [Internet]. 2004 [cited 2017 Mar 10]. Available from: http://dx.doi. org/10.2305/IUCN.UK.2004.RLTS.T44595A10912274.en

Walters CJ, Martell SJ. Fisheries ecology and management. Princeton: Princeton University Press; 2004.

Yokota L, Lessa RP. A nursery area for sharks and rays in Northeastern Brazil. Environ Biol Fishes. 2006; 75(3):349-60. 
